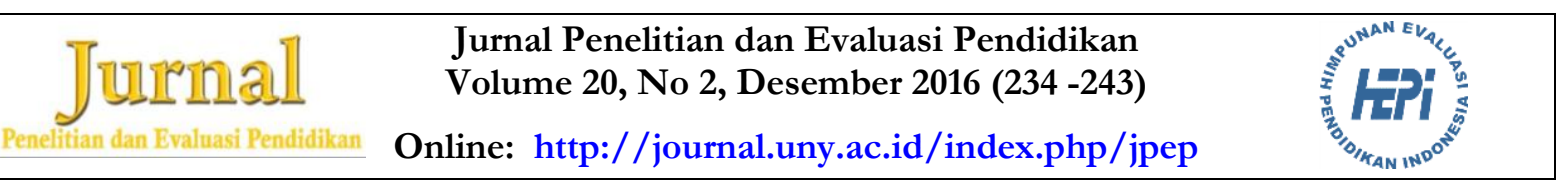

\title{
MODEL EVALUASI UJIAN NASIONAL KOMPETENSI KEAHLIAN TEKNIK PEMESINAN SMK
}

\author{
Slamet Wijono ${ }^{1}$, Djemari Mardapi ${ }^{2}$ \\ ${ }^{1}$ SMKN 2 Depok Sleman Yogyakarta, ${ }^{2}$ Universitas Negeri Yogyakarta \\ ${ }^{1}$ Mrican, Caturtunggal, Depok, Santren, Yogyakarta, 55281, Indonesia \\ ${ }^{2} J 1$. Colombo No. 1, Depok, Sleman 55281, Yogyakarta, Indonesia \\ slametwijono30@gmail.com,djemarimardapi@gmail.com, badrunkw@yahoo.com
}

\begin{abstract}
Abstrak
Penelitian ini bertujuan untuk: (1) mengidentifikasi komponen-komponen penyelenggaraan Ujian Nasional Kompetensi Keahlian (UNKK) Teknik Pemesinan SMK, (2) mengembangkan instrumen penyelenggaraan UNKK Teknik Pemesinan SMK, (3) menyusun panduan evaluasi penyelenggaraan UNKK Teknik Pemesinan SMK, dan (4) mengembangkan model evaluasi UNKK Teknik Pemesinan SMK. Teknik penyimpulan pendapat pakar dihitung dengan rumus Aiken; validitas konstruk instrumen dianalisis menggunakan confirmatory faktor analysis, goodness of-fit test ditentukan dengan kriteria $\mathrm{p}>0,05$; reliabilitas diestimasi menggunakan Cronbach Alpha. Hasil penelitian adalah sebagai berikut. (1) Komponen penyelenggaraan UNKK Teknik Pemesinan SMK mencakup: (a) kolaborasi sekolah dengan asosiasi profesi dan DU/DI, (b) kinerja asesor, (c) sarana dan prasarana, (d) pengetahuan siswa terhadap kegiatan UNKK SMK, (e) informasi capaian kompetensi siswa, dan (f) legalitas dan pengakuan asosiasi profesi dan DU/DI; (2) instrumen evaluasi dalam kategori baik dan uji keterbacaan instrumen dalam kategori baik atau layak digunakan, (3) Panduan penerapan instrumen evaluasi berdasarkan penilaian para pimpinan sekolah dan guru termasuk kategori layak untuk digunakan, dan (4) Uji kecocokan model evaluasi UNKK Teknik Pemesinan SMK memenuhi syarat fit model.
\end{abstract}

Kata kunci: model, evaluasi, ujian nasional kompetensi keablian teknik pemesinan SMK

\section{AN EVALUATION MODEL OF THE NATIONAL EXAMINATION OF EXPERTISE COMPETENCIES AT VHS}

\begin{abstract}
This study aims to: (1) identify the components of the implementation of the National Examination of Expertise Competencies (NEEC) at the vocational high school (VHS), (2) develop reliable and accurate instruments to evaluate the implementation of the NEEC at VHS, (3) develop guidelines for an evaluation of the NEEC at VHS, and (4) develop model for an evaluation of the NEEC at VHS. The expert judgment conclusions were calculated by the Aiken formula, the instrument construct validity was analyzed with confirmatory factor analysis by the goodness-of- fit test at level of significance $\mathrm{p}>0,05$, the reliability was estimated by Cronbach Alpha. The conclusions of the study are as follows. (1) The components of the implementation of the NEEC at VHS include: (a) the collaboration between schools and profession associations and business sectors/industrial sectors (BS/IS), (b) assessors' performances, (c) infrastructure facilities, (d) students' understanding of the NEEC at VHS, (e) information about the attainment of students' competencies, and ( $\mathrm{f}$ ) the legality and recognition from profession associations and BS/IS; (2) The developed evaluation instrument sets are good and the instrument readability test are good and appropriate to use; (3) The guideline for the application of the evaluation instruments, based on the assessment by principals and teachers, are appropriate to use; (4) The model for an evaluation of the NEEC at VHS matches fit model.
\end{abstract}

Keywords: model, evaluation, national examination of expertise competencie

Permalink/ DOI: bttp:/ / dx.doi.org/10.21831/pep.v20i2.8731

Jurnal Penelitian dan Evaluasi Pendidikan

ISSN 1410-4725 (print) ISSN 2338-6061 (online) 


\section{Pendahuluan}

Sumber daya manusia (SDM) idealnya secara nasional lulusan SMK yang bisa langsung memasuki dunia kerja sekitar 80$85 \%$, sedang selama ini yang terserap baru 61\%. Pada tahun 2006 lulusan SMK di Indonesia mencapai 628.285 orang, sedangkan proyeksi penyerapan atau kebutuhan tenaga kerja lulusan SMK tahun 2007 hanya 385.986 atau sekitar 61,43\% (Samsudi, 2008, p. 1).

Menghadapi kondisi tersebut, pendidikan menengah kejuruan diperhadapkan pada berbagai permasalahan, antara lain: masalah konsepsi, program dan operasional pendidikan. Keterserapan lulusan SMK di industri menjadi salah satu hal yang sangat penting karena industri merupakan institusi yang paling banyak menggunakan lulusan SMK sebagai tenaga kerja karena dianggap memiliki keahlian/kompetensi khusus dibanding lulusan SMU. Kenyataan di lapangan menunjukkan banyak industri/dunia usaha harus memberi pelatihan khusus bagi karyawan/tenaga kerja baru karena dianggap belum siap menjalankan tugasnya. Pelatihan awal yang diadakan oleh industri terutama bagi karyawan baru ini dimaksudkan agar tenaga kerja yang masuk sudah siap menjalankan tugasnya sesuai job yang ada dan kompetensi yang dimiliki sesuai dengan kompetensi yang diharapkan dengan bidang pekerjaannya

Ujian Nasional Kompetensi Keahlian (UNKK) Teknik Pemesinan SMK dilaksanakan pada tahun ke tiga yang salah satu tujuannya adalah untuk mengukur kemampuan siswa terhadap penguasaan kompetensi yang telah. UNKK Teknik Pemesinan SMK terdiri atas ujian teori kejuruan dan ujian praktik kejuruan. Untuk SMK yang menyelenggarakan pendidikan 4 tahun ujian teori diadakan pada tahun ketiga sedang ujian praktik diadakan pada tahun keempat. Kenyataan di lapangan pelaksanaan UNKK Teknik Pemesinan SMK masih ditemukan permasalahan. Berdasarkan latar belakang dan identifikasi masalah yang dikemukakan sebelumnya, model evaluasi dibatasi untuk UNKK Teknik Pemesinan SMK.
Berdasarkan uraiaan tersebut, maka penelitian ini bertujuan untuk: (1) mengidentifikasi komponen-komponen penyelenggaraan UNKK Teknik Pemesinan SMK, (2) mengembangkan instrumen penyelenggaraan UNKK Teknik Pemesinan SMK, (3) menyusun panduan evaluasi penyelenggaraan UNKK Teknik Pemesinan SMK, dan (4) mengembangkan model evaluasi Ujian Nasional Kompetensi Keahlian Teknik Pemesinan SMK.

\section{Metode Penelitian}

Penelitian ini termasuk dalam kategori penelitian dan pengembangan (research and development) yang sering disingkat $\mathrm{R} \& \mathrm{D}$, yaitu: (1) yaitu penelitian dan pengumpulan informasi dalam model ini disebut dengan penelitian pendahuluan atau investigasi awal; langkah (2) perencanaan dan (3) pengembangan produk awal, disebut tahap desain karena pada dasarnya kedua langkah tersebut merupakan tahap mendesain atau merancang produk, baik desain prosedur, instrumen, maupun panduan evaluasi; langkah (4) uji coba pendahuluan, (5) revisi produk utama, (6) uji coba utama, (7) revisi produk operasional dalam model ini disebut sebagai tahap uji coba, evaluasi, dan revisi; dan langkah (8) uji coba operasional lapangan, (9) revisi produk akhir, dan (10) diseminasi dan implementasi disebut sebagai tahap implementasi (Borg \& Gall, 1983, pp. 781-802).

Penelitian dilaksanakan pada bulan November 2014 sampai dengan bulan Desember 2015. Tempat penelitian di SMK Teknik Pemesinan di Daerah Istimewa Yogyakarta. Populasi peneltian adalah Sekolah Menengah Kejuruan kompetensi keahlian Teknik Pemesinan di Daerah Istimewa Yogyakarta. Sampel penelitian adalah guru dan siswa kompetensi keahlian Teknik Pemesinan SMK.

Prosedur pengembangan dalam penelitian ini menggunakan 5 langkah pengembangan, yaitu: (1) studi pendahuluan, (2) pengembangan model awal, (3) validasi ahli dan revisi, (4) uji lapangan skala kecil dan revisi, dan (5) uji lapangan skala besar dan produk akhir. 
Prasurvei dilakukan bekerja sama dengan asosiasi profesi atau DU/DI dilakukan pada awal bulan Oktober 2014 sampai pertengahan Bulan Desember 2015 yang melibatkan tiga DU/DI yaitu PT. Mega Andalan Kalasan, PT. Kripton Gamajaya, dan UD ED. Prasurvei dilakukan dengan pedoman wawancara terhadap karyawan DU/DI terkait yang terlibat langsung dengan pelaksanaan UNKK Teknik Pemesinan SMK. Dari hasil prasurvei dengan wawancara diperoleh gambaran komponen-komponen yang mempengaruhi kualitas penyelenggaraan UNKK Teknik Pemesinan SMK, yaitu; (1) kolaborasi sekolah dengan DU/DI, (2) sarana dan prasarana penunjang, dan (3) kinerja asesor. Sehingga dari hasil observasi di lapangan peneliti menetapkan enam komponen utama penyelenggaraan UNKK Teknik Pemesinan SMK, yaitu: (1) kolaborasi sekolah dengan asosiasi profesi atau DU/DI, (2) kinerja asesor, (3) sarana dan prasarana, (4) pengetahuan siswa terhadap UNKK Teknik Pemesinan SMK, (5) informasi capaian kompetensi siswa, dan (6) legalitas dan pengakuan asosiasi profesi atau DU/DI.

Berdasarkan hasil investigasi awal, kajian teori, dan hasil penelitian sebelumnya, dirancang model evaluasi UNKK Teknik Pemesinan SMK seperti dapat dilihat pada Gambar 2. Di samping itu, disusun pula desain uji coba model evaluasi UNKK Teknik Pemesinan SMK. Model yang dikembangkan menggunakan model IPO (Input, Proses, dan Output) dilengkapi dengan prosedur evaluasi, instrumen, dan panduan penggunaan. Tahap perencanaan ini merupakan kegitan menjabarkan komponen-komponen yang mempengaruhi kualitas penyelenggaraan UNKK Teknik Pemesinan SMK yang telah ditetapkan dari kajian pustaka, menjadi indikator yang relevan. Jabaran ini sekaligus menjadi draf model evaluasi UNKK Teknik Pemesinan SMK dan panduan evaluasinya.

Setelah draf awal instrumen evaluasi disusun, maka dilanjutkan dengan proses validasi kepada para pakar (expert judgement). Validasi pakar dimaksudkan untuk mendapatkan pertimbangan kepada orang yang dianggap lebih mengetahui cara pengem- bangan instrumen evaluasi dan perangkatnya. Proses validasi pakar dalam penelitian ini menggunakan model uji perorangan atau review ahli dilanjutkan dengan Fokus Group Discussion (FGD). Pakar (validator) pada penelitian ini adalah ahli (expert) dalam bidang pendidikan teknik pemesinan dan ahli evaluasi. Uji keterbacaan dilakukan kepada para guru SMK Kompetensi Keahlian Teknik Pemesinan SMK. Uji perorangan dengan review ahli secara teknis ditempuh dengan cara mengirimkan satu bendel draf awal instrumen dan panduan evaluasi. Hasil yang diperoleh dari review ahli tersebut dianalisis, dan kemudian digunakan sebagai bahan untuk melakukan revisi.

Uji coba dalam penelitian ini disamping responden dipersilakan memberikan penilaian melalui butir-butir pertanyaan, subjek coba juga diminta pendapatnya untuk memberikan penilaian tentang kelayakan instrumen berupa angket pengumpulan data, serta memberikan masukan mengenai panduan evaluasinya. Berdasarkan hasil analisis terhadap berbagai masukan dan pendapat pada uji coba ini, dilakukan pembenahan dan pengembangan sebelum dilakukan tahap uji coba ketiga atau uji lapangan skala besar.

Tahap uji coba lapangan diperluas merupakan langkah pengumpulan data lapangan, dengan menggunakan instrumen yang telah divalidasi. Setelah instrumen evaluasi dianggap sudah baik, kemudian diterapkan pada sekolah lain agar dapat dievaluasi sejauh mana hasil penerapannya. Pada tahap ini dilaksanakan uji lapangan skala besar. Pada uji coba ini, subjek coba yang digunakan menjadi lebih luas dibanding pada uji coba sebelumnya

Konversi data kuantitatif ke data kualitatif dengan skala 5 menggunakan aturan yang merupakan modifikasi dari aturan yang dikembangkan oleh Ebel (1979, p. 237) seperti disajikan pada Tabel 1 .

Penentuan validitas oleh pakar menggunakan formula Aiken's V. Aiken (1985) merumuskan formula Aiken's V untuk menghitung content-validity coefficient yang didasarkan pada hasil penilaian dari panel ahli 
sebanyak $\mathrm{n}$ orang terhadap suatu butir dari segi sejauh mana butir tersebut mewakili konstrak yang diukur. Formula yang diajukan oleh Aiken adalah sebagai berikut (Azwar, 2012, p. 113).

Tabel 1. Konversi Data Kuantitatif ke Kualitatif

\begin{tabular}{ccc}
\hline Rumus & $\begin{array}{c}\text { Rerata } \\
\text { Skor }\end{array}$ & Klasifikasi \\
\hline $\mathrm{X}>\mathrm{M}+1,5 \sigma$ & $>4,0$ & $\begin{array}{c}\text { Sangat Layak/ } \\
\text { Sangat Baik } \\
\text { Layak/ } \\
\text { Baik }\end{array}$ \\
$\mathrm{M}-0,5 \sigma<\mathrm{X} \leq \mathrm{M}+0,5 \sigma$ & $>2,7-3,3$ & $\begin{array}{c}\text { Cukup Layak/ } \\
\text { Cukup Baik }\end{array}$ \\
$\mathrm{M}-1,5 \sigma<\mathrm{X} \leq \mathrm{M}-0,5 \sigma$ & $>2,0-2,7$ & $\begin{array}{c}\text { Kurang Layak/ } \\
\text { Kurang Baik }\end{array}$ \\
& $>3,3-4,0$ & $\begin{array}{c}\text { Sangat Kurang } \\
\text { Layak/ } \\
\text { Sangat Kurang } \\
\text { Baik }\end{array}$ \\
\hline $\mathrm{X} \leq \mathrm{M}-1,5 \sigma$ & $\leq 2,0$ & \\
& & .
\end{tabular}

Keterangan:

$\mathrm{M}=$ median

$\sigma=$ simpangan baku ideal $=1 / 6$ (skor maksimum ideal-skor minimum ideal)

$\mathrm{X}=$ skor empiris

Instrumen pengumpulan data dianalisis dengan Second Order Confirmatory Factor Analysis (CFA) program Lisrel 8.51. Ghozali \& Fuad (2005, p. 157) mengatakan bahwa second order confirmatory digunakan apabila satu faktor laten memiliki beberapa indikator, dan indikator-indikator tersebut tidak langsung dapat diukur karena memerlukan indikator lagi. Apabila nilai alpha lebih besar dari $5 \%$ dan nilai t kurang dari $t_{\text {tabel }}$ yaitu sebesar 1,96 (pada diagram second order menunjukkan warna merah) berarti nomor butir yang bersangkutan masuk dalam kategori tidak valid dan harus dibuang. Sebaliknya, apabila nilai t lebih besar dari $t_{\text {tabel }}$ sebesar 1,96 (pada diagram secong order menunjukkan warna hitam), maka nomor butir tersebut termasuk dalam kategori valid.

Selain untuk menganalisis validitas butir instrumen, Lisrel digunakan juga untuk menguji kecocokan model pengukuran (fit model). Sebuah model dikatakan cocok (fit) apabila model teoretis atau model hipotetik yang dikembangkan pada penelitian cocok (fit) didukung oleh data empiris (Ghozali \& Fuad, 2005, pp. 29-31). Model hipotetik yang diuji secara empiris dalam penelitian ini adalah instrumen evaluasi UNKK Teknik Pemesinan SMK. Validitas butir dengan menggunakan program LISREL 8.51 didasarkan pada besarnya muatan faktor lebih besar dari 0,3 maka butir instrumen tersebut dianggap valid (Fernandes, 1984, p. 28). Kriteria Goodness of Fit menurut (Hair, Anderson, Tatham, \& Black, 1998), syarat fit model jika probability Value $(\mathrm{P}) \geq 0,05$, RMSEA (Root Mean Square Error Approximation) $<0,1$, dan GFI (Goodness of Fit Indices) > 0,9.

Reliabilitas diestimasi dengan formula Cronbach's Alpha menggunakan program SPSS Statistics 17.0, dengan pertimbangan bahwa opsi jawaban yang dikembangkan dalam instrumen ini dengan skala Likert. Dengan demikian, untuk mengetahui reliabilitas konstruk dilakukan dengan melihat nilai koefisien Cronbach's Alpha, yaitu sekurang-kurangnya 0,7 . Hal ini sesuai dengan pendapat (Mardapi, 2008, p. 121), indeks keandalan instrumen dapat dihitung dengan formula Cronbach's Alpha, bila besarnya indeks sama atau lebih besar dari 0,7 maka instrumen itu tergolong baik.

Validitas model konseptual dilakukan melalui Focus Group Discussion (FGD). Model dikatakan valid berdasarkan hasil diskusi dan kesepakatan para ahli peserta focus group discussion. Disamping kesepakatan para ahli, validitas model diperoleh dari hasil analisis dengan model struktural. Model struktural evaluasi UNKK Teknik Pemesinan SMK seperti Gambar 1. 


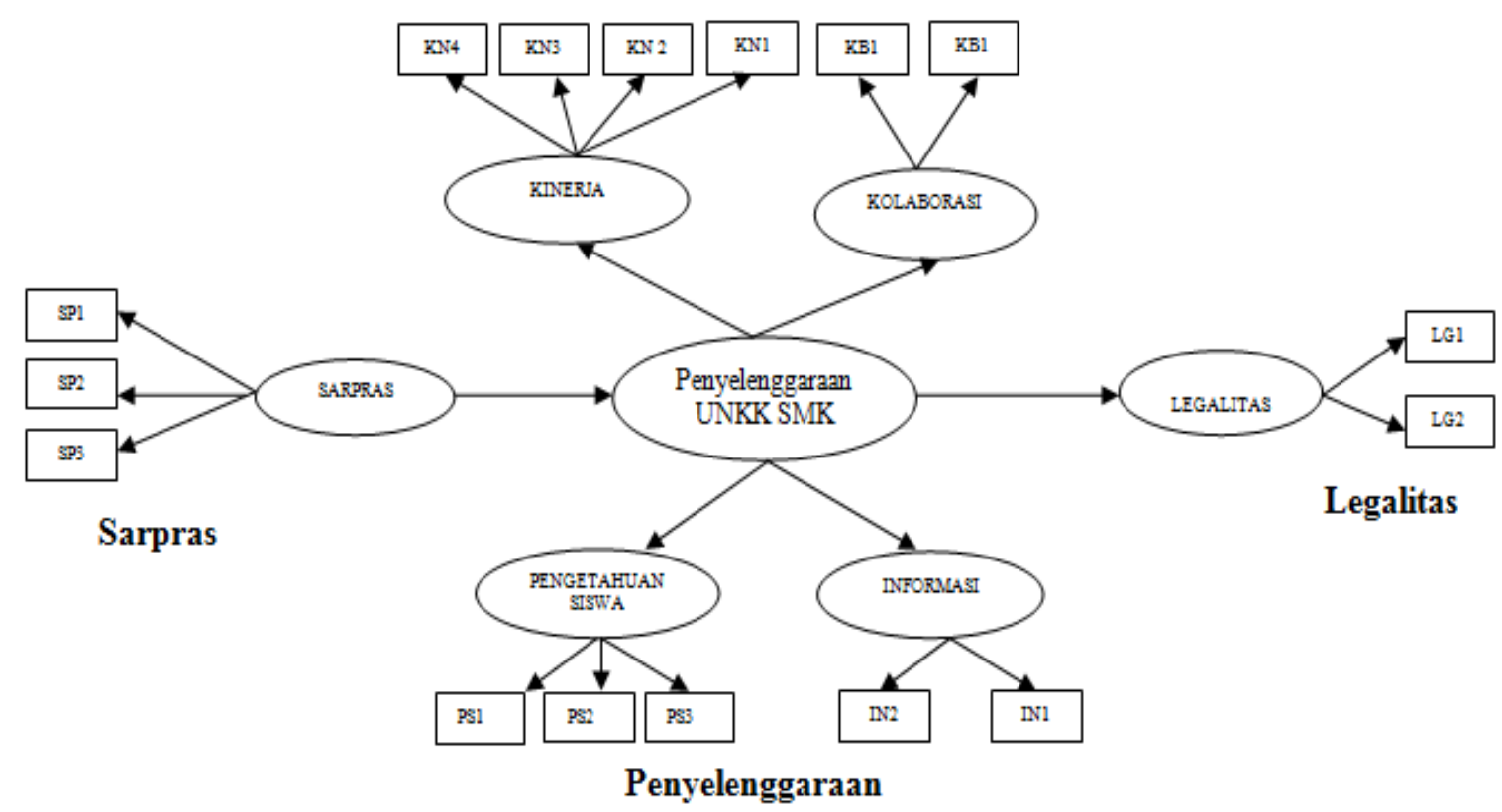

Gambar 1. Model struktural evaluasi UNKK Teknik Pemesinan SMK

\section{Hasil Penelitian dan Pembahasan}

Hasil studi pendahuluan dengan observasi awal di SMK dan wawancara dengan beberapa guru teknik pemesinan, ditetapkan tiga jenis SMK, yaitu (1) SMK Negeri wilayah kota, (2) SMK negeri wilayah kabupaten, dan (3) SMK swasta berbasis yayasan sosial/pendidikan. Hasil prasurvei dengan wawancara, mencakup: (1) peralatan ujian kompetensi belum memenuhi standar industri; (2) hasil pekerjaan siswa belum sesuai presisi/ukuran yang diharapkan; (3) kompetensi lulusan SMK teknik pemesinan belum memenuhi standar kompetensi DU/ DI; (4) kurangya kerja sama/kolaborasi antara sekolah, DU/DI dan pemerintah; (5) perlunya pembinaan awal/diklat bagi lulusan SMK yang diterima di DU/DI.

Melalui proses panjang yang diawali dengan studi literatur, penyusunan draf awal, validasi melalui FGD para pakar, ditetapkan komponen-komponen penyelenggaraan UNKK Teknik Pemesinan SMK yang menjadi dasar penjabaran menjadi konstruk teoretik dan indikator instrumen, mencakup: (1) kolaborasi sekolah dengan asosiasi profesi atau DU/DI; (2) kinerja asesor, (3) sarana dan prasarana; (4) pengetahuan siswa terhadap Ujian Nasional Kompetensi Ke- ahlian; (5) informasi capaian kompetensi siswa; dan (6) legalitas dan pengakuan asosiasi profesi atau DU/DI.

Kajian teoretis, empiris, dan menyaring masukan dari berbagai pihak melalui review ahli dan uji coba lapangan, mengarah pada ditemukannya konsep komponenkomponen penyelenggaraan kegiatan UNKK Teknik Pemesinan SMK. Selanjutnya produk pengembangan dideskripsikan pada Buku Panduan Instrumen Evaluasi UNKK Teknik Pemesinan SMK.

Pelaksanaan FGD diselenggarakan pada Rabu, 12 Agustus 2015 dengan melibatkan berbagai pihak insternal yaitu guru SMK teknik pemesinan serta pihak eksternal yaitu pakar evaluasi dan praktisi pendidikan teknik pemesinan. Jumlah peserta 6 orang, yaitu guru SMK teknik pemesinan 1 orang, pakar evaluasi dan praktisi pendidikan teknik pemesinan 5 orang.

Validasi pakar dengan menggunakan skala 5, dengan skor minimal 1 dan skor maksimal 5. Analisis validasi pakar dengan menggunakan formula Aiken's V (1985). Adapun hasil penilaian pakar terhadap validitas isi, semua butir dalam instrumen $\geq 0,7$ sehingga butir layak untuk digunakan.

Validasi terhadap keterbacaan instrumen dalam uji coba terbatas melibatkan 10 
orang, terdiri guru kompetensi keahlian teknik pemesinan 8 orang dan pakar evaluasi 2 orang. Adapun hasil penilaian terhadap keterbacaan instrumen diperoleh rerata skor di atas 3,7.

Penilaian panduan penerapan instrumen evaluasi dalam uji coba terbatas berjumlah 10 orang, yakni terdiri dari pakar evaluasi ( 2 orang) dan guru kompetensi keahlian teknik pemesinan (8 orang). Penilaian menggunakan skala 5 , yakni skor minimal 1 dan skor maksimal 5. Rerata skor hasil penilaian uji terbatas terhadap panduan evaluasi dalam penelitian rerata skor di atas 3,80 .

Reliabilitas instrumen melibatkan subjek coba yaitu 50 orang guru dan 90 siswa, dan dilaksanakan di SMKN 2 Yogyakarta, SMKN 2 Depok Sleman, SMK Negeri 1 Sedayu Bantul dan SMK Muhammadiyah 3 Yogyakarta. Untuk subjek coba siswa berasal dari kelas XII Kompetensi Keahlian Teknik Pemesinan yang telah selesai mengikuti UNKK Teknik Pemesinan (40 orang Siswa SMKN 2 Depok, 20 orang Siswa SMKN 2 Yogyakarta, 15 orang siswa SMK negeri 1 Sedayu dan 15 orang Siswa SMK Muhammadiyah 3 Yogyakarta). Jumlah keseluruhan siswa 90 ditambah subjek guru 50 orang sehingga jumlah subjek uji coba pada uji coba utama ini adalah 140 orang.

Reliabilitas konstruk dilakukan dengan melihat nilai koefisien Cronbach's Alpha sekurang-kurngnya 0,7. Berdasarkan kriteria tersebut, hasil analisis reliabilitas responden siswa diperoleh koefisien Alpha di atas 0,7.

Pada uji lapangan skala besar ini untuk penilaian instrumen evaluasi dan panduannya melibatkan 20 orang, yakni terdiri guru teknik pemesinan dan pimpinan sekolah. Uji coba instrumen untuk membuktikan validitas butir instrumen melibatkan subjek coba yang lebih besar, yaitu 200 orang guru dan 250 siswa, dan dilaksanakan di SMK kompetensi keahlian teknik pemesinan Negeri maupun swasta di Daerah Istimewa Yogyakarta.

Validator keterbacaan instrumen dalam uji coba diperluas berjumlah 20 orang yang terdiri guru dan pimpinan sekolah. Pe- nilaian keterbacaan instrumen menggunakan skala 5, yaitu skor minimal 1 dan skor maksimal 5. Rerata skor hasil penilaian uji coba diperluas terhadap keterbacaan instrumen diperoleh skor rerata $\geq 3,9$.

Analisis uji coba diperluas konstuk variabel Kolaborasi Sekolah dengan Asosiasi Profesi atau DU/DI untuk responden siswa diperoleh nilai muatan faktor $>0,3$ dan $\mathrm{t}>1,96$ untuk setiap butir instrumen. Reliabilitas konstruk koefisien Cronbach's Alpha sekurang-kurangnya 0,7. Berdasarkan hasil pengujian model persamaan struktural Kolaborasi Sekolah dengan Asosiasi Profesi atau DU/DI, ditemukan nilai Chi-Square= 19,91, $\mathrm{p}=0,09740$, nilai RMSEA $=0,046<$ 0,1 dan GFI $=0,98>0,90$. Hal tersebut menunjukkan bahwa model teoretis yang dikembangkan pada penelitian ini cocok (fit) dengan model yang diperoleh dari data empiris.

Hasil analisis konstuk variabel kinerja asesor untuk responden siswa diperoleh nilai muatan faktor $>0,3$ dan $\mathrm{t}>1,96$ untuk setiap butir instrumen, Reliabilitas konstruk nilai koefisien Cronbach's Alpha sekurangkurangnya 0,7 . Berdasarkan hasil pengujian model persamaan struktural kinerja asesor, ditemukan nilai Chi-Square $=170,15, \quad p=$ 0,10262 , nilai RMSEA $=0,025<0,1$ dan GFI $=0,93>0,90$. Hal tersebut menunjukkan bahwa model teoretis yang dikembangkan pada penelitian ini cocok (fit).

Hasil analisis pada uji coba konstruk variabel sarana dan prasarana untuk responden siswa diperoleh nilai muatan faktor $>$ 0,3 dan $t>1,96$ untuk setiap butir instrumen, Reliabilitas konstruk dilakukan dengan melihat nilai koefisien Cronbach's Alpha sekurang-kurangnya 0,7. Berdasarkan hasil pengujian model persamaan struktural sarana dan prasarana, ditemukan nilai $C h i-$ Square $=45,87, \mathrm{p}=0,31469$, nilai $\mathrm{RMSEA}=$ $0,019<0,1$ dan GFI $=0,97>0,90$. Hal tersebut menunjukkan bahwa model teoretis yang dikembangkan pada penelitian ini cocok (fit) dengan model yang diperoleh dari data empiris. 
Hasil analisis pada uji coba diperluas konstruk variabel sikap siswa terhadap kegiatan UNKK Teknik Pemesinan SMK untuk responden siswa diperoleh nilai muatan faktor $>0,3$ dan $t>1,96$ untuk setiap butir instrumen, sedangkan reliabilitas konstruk koefisien Cronbach's Alpha sekurangkurangnya 0,7

Untuk mengestimasi reliabilitas gabungan, (McDonald, 1981) merumuskan koefisien reliabilitas skor komposit yang dinamakan koefisien omega $(\omega)$.

$$
\omega \frac{\left[\sum_{1}^{i} \lambda_{i}\right]^{2}}{\left[\sum_{1}^{i} \lambda_{i}\right]^{2}+\left[\sum_{1}^{i} 1-\lambda_{i}^{2}\right]}
$$

Keterangan:

$$
\begin{aligned}
\lambda_{i}= & \text { factor loading terstandardisasi indikator } \\
& \mathrm{ke}-\mathrm{i}
\end{aligned}
$$

Untuk reliabilitas skor komposit McDonald, dengan menggunakan program LISREL 8.51 dan Excel didapat koefisien reliabilitas $\omega=0,97$,

Berdasarkan hasil pengujian model persamaan struktural sikap siswa terhadap kegiatan UNKK Teknik Pemesinan SMK, ditemukan nilai Chi-Square $=78,16, \mathrm{p}=$ 0,37868 , dan GFI $=0,96>0,90$. Hal tersebut menunjukkan bahwa model teoretis yang dikembangkan pada penelitian ini cocok (fit). Hasil analisis pada uji coba diperluas konstruk variabel informasi capaian kompetensi siswa untuk responden siswa diperoleh nilai muatan faktor $>0,3$ dan $t>1,96$ untuk setiap butir instrumen, Reliabilitas konstruk koefisien Cronbach's Alpha sekurang-kurangnya 0,7 . Berdasarkan hasil pengujian model persamaan struktural informasi capaian kompetensi siswa, ditemukan nilai ChiSquare $=45,21, \mathrm{p}=0,09464$, nilai RMSEA $=$ $0,036<0,1$ dan GFI $=0,96>0,90$. Hal tersebut menunjukkan bahwa model teoretis yang dikembangkan pada penelitian ini cocok (fit).

Hasil analisis pada uji coba konstruk variabel legalitas asosiasi profesi atau DU/ DI untuk responden siswa diperoleh nilai muatan faktor $>0,3$ dan $\mathrm{t}>1,96$ untuk se- tiap butir instrumen, Reliabilitas konstruk koefisien Cronbach's Alpha sekurang-kurangnya 0,7 . Berdasarkan hasil pengujian model persamaan struktural legalitas asosiasi profesi atau DU/DI, ditemukan nilai Chi-Square $=44,84, \mathrm{p}=0,10111$, nilai RMSEA $=0,036$ $<0,1$ dan GFI $=0,97>0,90$. Hal tersebut menunjukkan bahwa model teoretis yang dikembangkan pada penelitian ini cocok (fit).

Hasil analisis dengan responden guru pada uji coba skala besar konstruk variabel kolaborasi sekolah dengan asosiasi profesi atau DU/DI diperoleh nilai muatan faktor $>0,3$ dan $t>1,96$ untuk setiap butir instrumen. Reliabilitas konstruk dilakukan dengan melihat nilai koefisien Cronbach's Alpha sekurang-kurangnya 0,7 . Berdasarkan hasil pengujian model persamaan struktural kolaborasi sekolah dengan asosiasi profesi atau DU/DI dengan responden guru, ditemukan nilai Chi-Square $=159,24, \mathrm{p}=0,24946$ nilai RMSEA $=0,020<0,1$ dan GFI $=0,92>$ 0,90 . Hal tersebut menunjukkan bahwa model teoretis yang dikembangkan pada penelitian ini cocok (fit) dengan model yang diperoleh dari data empiris.

Hasil analisis pada uji coba diperluas konstruk variabel sarana dan prasarana dengan responden guru diperoleh nilai muatan faktor $>0,3$ dan $t>1,96$ untuk setiap butir instrumen. Reliabilitas konstruk koefisien Cronbach's Alpha sekurang-kurangnya 0,7. Berdasarkan hasil pengujian model persamaan struktural sarana dan prasarana dengan responden guru, ditemukan nilai ChiSquare $=47,03, \mathrm{p}=0,23918$, nilai $\mathrm{RMSEA}=$ $0,027<0,1$ dan GFI $=0,96>0,90$. Hal tersebut menunjukkan bahwa model teoretis yang dikembangkan pada penelitian ini co$\operatorname{cok}($ fit).

Hasil analisis pada uji coba konstruk variabel informasi capaian kompetensi siswa dengan responden guru diperoleh nilai muatan faktor $>0,3$ dan $t>1,96$ untuk setiap butir instrumen. Reliabilitas konstruk Cronbach's Alpha sekurang-kurangnya 0,7. Berdasarkan hasil pengujian model persamaan struktural informasi capaian kompetensi siswa dengan responden guru, ditemukan nilai Chi-Square $=36,49, \mathrm{p}=0,35387$, 
nilai $\mathrm{RMSEA}=0,027<0,1$ dan GFI $=0,93$ $>0,90$. Hal tersebut menunjukkan bahwa model teoretis yang dikembangkan pada penelitian ini cocok (fit).

Hasil analisis pada uji lapangan skala besar konstruk variabel legalitas dan pengakuan asosiasi profesi atau DU/DI dengan responden guru diperoleh nilai muatan faktor $>0,3$ dan $\mathrm{t}>1,96$ untuk setiap butir instrumen. Reliabilitas Cronbach's Alpha sekurang-kurangnya 0,7. Berdasarkan hasil pengujian model persamaan struktural legalitas dan pengakuan asosiasi profesi atau DU/DI dengan resonden guru, ditemukan nilai Chi-Square $=28,17, \mathrm{p}=0,74853$, nilai
RMSEA $=0,000<0,1$ dan GFI $=0,95>$ 0,90 . Hal tersebut menunjukkan bahwa model teoretis yang dikembangkan pada penelitian ini cocok (fit).

Hasil pengujian kecocokan model evaluasi UNKK Teknik Pemesinan SMK dengan data empiris dapat dilihat pada Gambar 2. Berdasarkan hasil pengujian model persamaan struktural, ditemukan nilai Chi-Square $=122,02, \mathrm{p}=0,05054$, nilai RMSEA $=0,031<0,1$ dan GFI $=0,94>0,90$. Hal tersebut menunjukkan bahwa model teoretis yang dikembangkan pada penelitian ini cocok (fit).

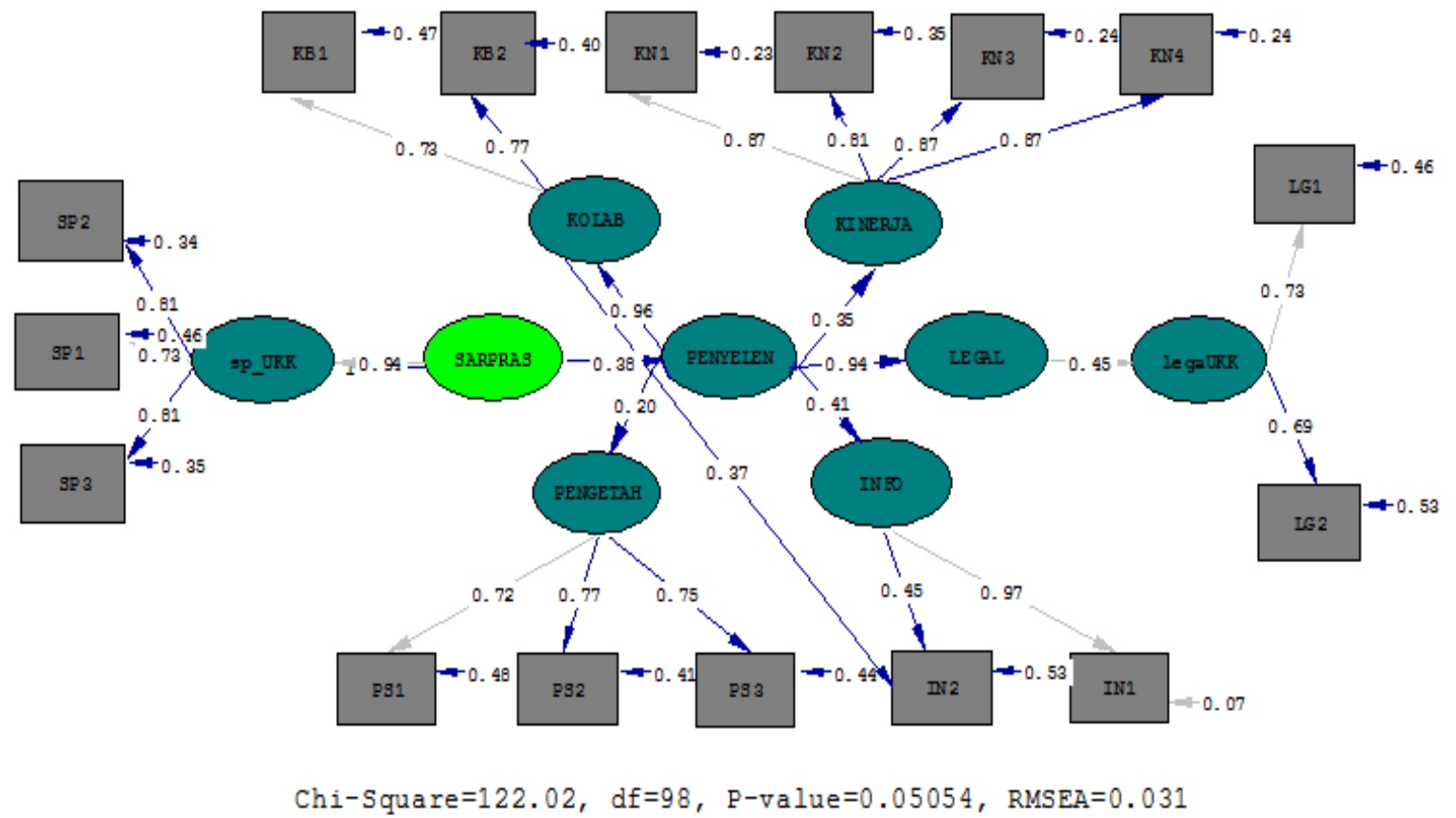

Gambar 2. Hasil Uji Model Pengukuran (Konstruk) Model Evaluasi UNKK Teknik Pemesinan SMK

Keterangan:

PENYELEN : Penyelenggaraan UNKK Teknik Pemesinan SMK

LEGAL : Legalitas dan Pengakuan Asosiasi Profesi atau DU/DI

SARPRAS : Sarana dan Prasarana UNKK

PENGETAH : Pengetahuan Siswa Terhadap Kegiatan UNKK

INFO : Informasi capaian Kompetensi

KINERJA : Kinerja Asesor

LEGAL : Legalitas Asosiasi Profesi atau DU/DI 
Hasil uji kuantitatif dianalisis dengan second order confirmatori factor analysis (CFA) menunjukkan bahwa butir-butir instrumen yang dikembangkan merupakan butir yang valid dan butir tersebut reliabel. Selain itu, instrumen evaluasi UNKK Teknik Pemesinan SMK merupakan model instrumen evaluasi yang sesuai atau cocok untuk mengevaluasi kualitas penyelenggaraan UNKK Teknik Pemesinan SMK, karena model tersebut secara statistik model pengukurannya didukung oleh data lapangan. Selain itu, didukung panduan yang singkat tetapi lengkap akan mempermudah penerapan sistem evaluasi UNKK Teknik Pemesinan SMK.

Penilaian panduan penerapan instrumen evaluasi dalam uji coba diperluas berjumlah 20 orang terdiri dari guru pendidikan teknik pemesinan dan pimpinan sekolah. Penilaian menggunakan skala 5, yakni skor minimal 1 dan skor maksimal 5. Rerata skor hasil penilaian terhadap panduan evaluasi yang dikembangkan dalam penelitian ini diperoleh rerata skor $\geq 3,90$.

\section{Simpulan dan Saran}

Simpulan

Berdasarkan hasil FGD dan analisis data disimpulkan sebagai berikut. Pertama, berdasarkan hasil diskusi dan kesepakatan para ahli dalam FGD, model evaluasi UNKK Teknik Pemesinan SMK yang dikembangkan, dinyatakan valid dan sesuai dengan teori yang menjadi landasan perancangan model tersebut.

Kedua, instrumen yang dikembangkan memenuhi syarat validitas dan reliabilitas, muatan faktor $>0,3$, nilai $t>1,96$, dan koefisien reliabilitas $\alpha>0,70$, serta memenuhi kriteria sebagai fit model RMSE $A$ $<0,10$ dan $G F I>0,90$ sehingga layak digunakan oleh pimpinan sekolah untuk mengevaluasi kualitas penyelenggaraan UNKK SMK, keterbacaan instrumen menunjukkan instrumen evaluasi penyelenggaraan UNKK SMK dalam kategori baik atau layak digunakan, rerata skor 3,95 dari skor maksimal 5; (3) panduan penerapan instrumen evaluasi menunjukkan bahwa panduan pe- nerapan instrumen evaluasi dalam kategori layak untuk digunakan, rerata skor 3,95 dari skor maksimal 5; (4) model evaluasi UNKK SMK memenuhi kriteria sebagai fit model RMSE $A<0,10$ dan GFI $>0,90$ sehingga layak digunakan oleh pimpinan sekolah untuk mengevaluasi kualitas penyelenggaraan UNKK SMK

Saran

Produk pengembangan perlu didesiminasikan dan diimplementasikan untuk melakukan evaluasi terhadap kualitas penyelenggaraan UNKK Teknik Pemesinan SMK. Sebaiknya evaluasi dilaksanakan segera setelah kegiatan UNKK Teknik Pemesinan SMK. Hal tersebut dimaksudkan agar diperoleh informasi yang aktual dan akurat dalam melakukan evaluasi terhadap pelaksanaan UNKK Teknik Pemesinan SMK.

\section{Daftar Pustaka}

Aiken, L. R. (1985). Three Coefficients for Analyzing the Reliability and Validity of Ratings. Educational and Psychological Measurement, 45(1), 131-142. https://doi.org/10.1177/0013164485 451012

Azwar, S. (2012). Reliabiltas dan validitas (4th ed.). Yogyakarta: Pustaka Pelajar.

Borg, W. R., \& Gall, M. D. (1983). Educational research: An introduction (4th ed.). New York: Longman Publishing.

Ebel, R. L. (1979). Essentials of educational measurement. New Jersey: Prentice-Hall Inc.

Fernandes, H. J. X. (1984). Evaluation of educational programs. Jakarta: National Education Planning, Evaluation and Curriculum Development.

Ghozali, I., \& Fuad. (2005). Structural equation modeling. Teori, konsep dan aplikasi dengan program Lisrel 8.80. Semarang: Badan Penerbit Universitas Diponegoro.

Hair, J. F., Anderson, R. E., Tatham, R. L., \& Black, W. (1998). Multivariate data 
analysis. New Jersey: Prentice-Hall, Inc.

Mardapi, D. (2008). Teknik penyusunan instrumen tes dan nontes. Yogyakarta: Mitra Cendikia Press.

McDonald, R. P. (1981). The dimensionality of tests and items. British Journal of Mathematical and Statistical Psychology,
34(1), 100-117.

https://doi.org/10.1111/j.2044-

8317.1981.tb00621.x

Samsudi. (2008). Daya serap lulusan SMK masih rendah. Republika Online. Retrieved from http://202.155.208./cetak_beritaasp?i $\mathrm{d}=328575 \&$ kat_id $=23 \&=$ Online 